CZASOPISMO INŻYNIERII LĄDOWEJ, ŚRODOWISKA I ARCHITEKTURY JOURNAL OF CIVIL ENGINEERING, ENVIRONMENT AND ARCHITECTURE

JCEEA, t. XXXIII, z. 63 (4/16), październik-grudzień 2016, s. 495-503

\author{
Adam RYBKA ${ }^{1}$
}

Michał KRUPA ${ }^{2}$

\title{
WSPÓŁCZESNA ARCHITEKTURA HISTORYCZNEGO CENTRUM SKAWINY NA TLE DZIEDZICTWA MIASTA - WYBRANE PRZYKLADY
}

\begin{abstract}
W przedmiotowym artykule przedstawiono wybrane problemy ochrony krajobrazu kulturowego centrum Skawiny w kontekście współczesnych realizacji architektonicznych, które powstały na tym terenie w ciągu ostatnich 15 lat.

Skawina ma bogate dziedzictwo kulturowe, a geneza jego powstania wiąże się z polityką króla Kazimierza Wielkiego, który na terenach nadgranicznych w wieku XIV zakładał miasta i zamki warowne. W drugiej połowie XX wieku w mieście zrealizowano inwestycje związane z przemysłem ciężkim, co miało zdecydowanie negatywny wpływ na środowisko naturalne, ale także na dziedzictwo kulturowe miasta, które pogrążyło się w stagnacji. W oczach wielu mieszkańców, a także przyjezdnych Skawina stała się jedynie ośrodkiem przemysłowym, zaś jej średniowieczne korzenie i historia uległa niemal całkowitemu zapomnieniu. W ciągu ostatnich 20 lat miasto zaczęło się prężnie rozwijać. Dzięki funduszom europejskim zmodernizowano infrastrukturę komunikacyjną i odnowiono rynek, co sprawiło, że mieszkańcy miasta oraz zewnętrzni inwestorzy zaczęli modernizować istniejącą zabudowę, a na niezabudowanych jeszcze posesjach budować nowe obiekty, przeznaczone w większości pod funkcję handlową i usługową. Inwestycje te prowadzone są niejednokrotnie w zabytkowym centrum Skawiny. Niniejszy artykuł ma na celu analizę kierunków współczesnej architektury miasta w kontekście jego historii. Autorzy spróbują odpowiedzieć na pytanie jak nowe obiekty i przebudowy wpływają na krajobraz kulturowy miasta.
\end{abstract}

Słowa kluczowe: Skawina, architektura współczesna, środowisko zabytkowe

\section{Wprowadzenie}

Skawina jest podkrakowskim ośrodkiem miejskim o średniowiecznym rodowodzie. Obecnie zamieszkuje go około 30000 mieszkańców. Miasto powstało na mocy aktu lokacyjnego wystawionego w 1364 roku przez króla Kazimierza

\footnotetext{
1 Adam Rybka, Politechnika Rzeszowska, Zakład Urbanistyki i Architektury, Al. Powstańców Warszawy 12, 35-959 Rzeszów; tel. 17865 1658; akbyr@prz.edu.pl

2 Autor do korespondencji / corresponding author: Michał Krupa, Politechnika Rzeszowska, Zakład Urbanistyki i Architektury, Al. Powstańców Warszawy 12, 35-959 Rzeszów; tel. 17 8651691; mkrupa@prz.edu.pl
} 
Wielkiego, który w XIV wieku tworzył system umocnień obronnych państwa polskiego fundując nowe miasta warowne, modernizując istniejące oraz budując zamki wzdłuż najbardziej zagrożonych granic kraju [1]. W kolejnych wiekach miasto wielokrotnie nękane było najazdami obcych wojsk, licznymi pożarami oraz zarazami. W wyniku tych kataklizmów, praktycznie od okresu średniowiecza, przestało się systematycznie rozwijać. Dopiero druga połowa XIX wieku i początek XX - okres związany z budową w mieście kolei oraz pierwszych zakładów przemysłowych takich jak: browar, rafineria nafty, Fabryka Wyrobów Kamionkowych i Szamotowych oraz Fabryka Kawy Zbożowej i Cykorii Henryka Franka dał szansę Skawinie na podniesienie się z marazmu [2].

Okres ostatnich 15 lat to czas wzmożonego naporu inwestycyjnego nie tylko w tzw. strefie ekonomicznej miasta, ale także w jego centrum, które do dzisiaj posiada wysokie wartości kulturowe. Właśnie te wartości zobowiązują inwestorów i projektantów to tego, aby nowa architektura oraz modernizacje obiektów istniejących wykonywać z dbałością oraz w poszanowaniu historycznych korzeni miasta. Nie oznacza to negacji nowej formy architektonicznej, ale jej dogłębną analizę w kontekście historycznego otoczenia. Zabytkowa struktura urbanistyczna miasta oraz architektura jego centrum, pochodząca w większości z XIX wieku, w wielu przypadkach nie jest wystarczająco dobrze chroniona w zapisach Miejscowego Planu Zagospodarowania Przestrzennego (dalej: MPZP), przez co może zostać bezpowrotnie zniszczona na skutek niekontrolowanego naporu inwestycyjnego.

Poniżej krótko scharakteryzowano krajobraz kulturowy miasta, a na jego tle zaprezentowano kilka przykładów współczesnych interwencji projektowych w centrum Skawiny. Część z nich dobrze koresponduje z zabytkowym otoczeniem. Są jednak przykłady zdecydowanie negatywne, które burzą ład przestrzenny i niszczą krajobraz kulturowy tego zabytkowego ośrodka.

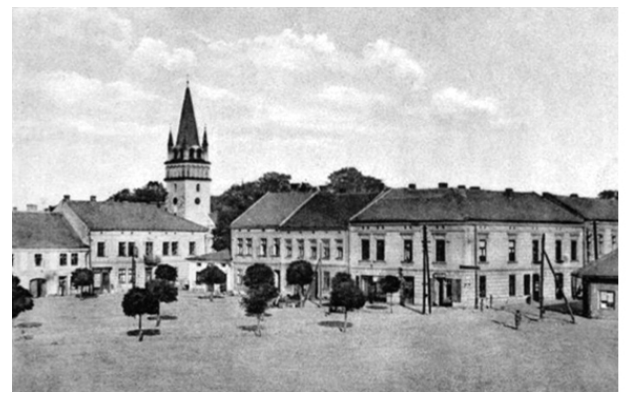

Ryc. 1. Widok na rynek w Skawinie w pierwszej połowie XX wieku. Fot. [w:] Archiwum Autora

Fig. 1.View of the market square in Skawina in the 1st half of the 20th century. Photo: [in:] Archive of Author

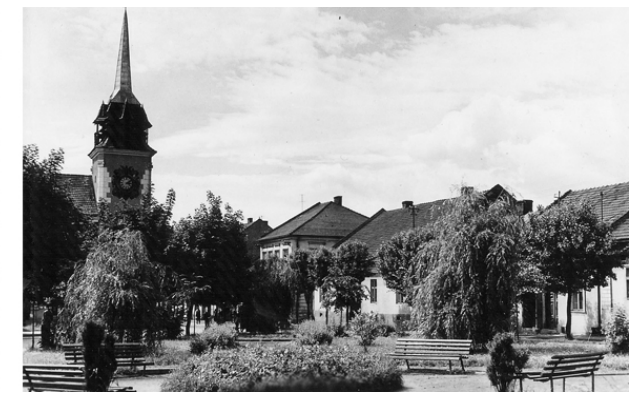

Ryc. 2. Widok na rynek w Skawinie w latach 60-tych XX wieku. Fot. [w:] Archiwum Autora

Fig. 2. View of the market square in Skawina in the 1960s. Photo: [in:] Archive of Author 


\section{Krajobraz kulturowy i historyczne dziedzictwo Skawiny}

Jak wspomniano we wstępie niniejszej pracy Skawina ma rodowód średniowieczny. $Z$ okresu lokacji do naszych czasów zachował się niemal niezmieniony układ urbanistyczny rynku i otaczających go bloków zabudowy oraz kościół parafialny pw. śś. Szymona i Judy. Inne, ważniejsze obiekty zabytkowe na terenie miasta to: XVII-wieczny kościół pw. NMP (pełniący w przeszłości funkcję kościoła szpitalnego); dawna XVIII-wieczna karczma, budynek Sokoła wzniesiony na pocz. XX w. w miejscu nieistniejącego obecnie zamku fundacji Kazimierza Wielkiego oraz ratusz z przełomu XIX i XX wieku projektu W. Ekielskiego [3]. Krajobraz kulturowy miasta tworzą obecnie także relikty obiektów przemysłowych, które powstały w Skawinie pod koniec XIX wieku. Do czasów obecnych zachowały się częściowo zabudowania dawnego browaru oraz Fabryki Kawy Zbożowej i Cykorii Henryka Franka [4]. Wymienione zabytki to tylko część dziedzictwa kulturowego miasta, który należy chronić i rewaloryzować. Nowe inwestycje architektoniczne lub przebudowy obiektów istniejących nie powinny naruszać ładu przestrzennego miasta, ale nową formą i estetyką winny go uatrakcyjniać.

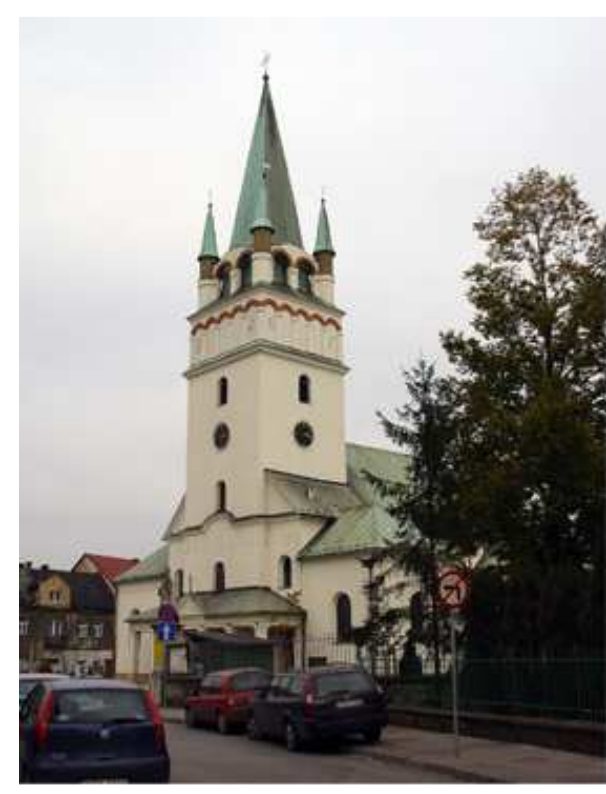

Ryc. 3. Kościół pw. śś. Szymona i Judy w Skawinie. Stan istniejący. Fot. M. Krupa, 2015 r.

Fig. 3. Church of St. Simon and Jude in Skawina. Present state. Photo: M. Krupa, 2015

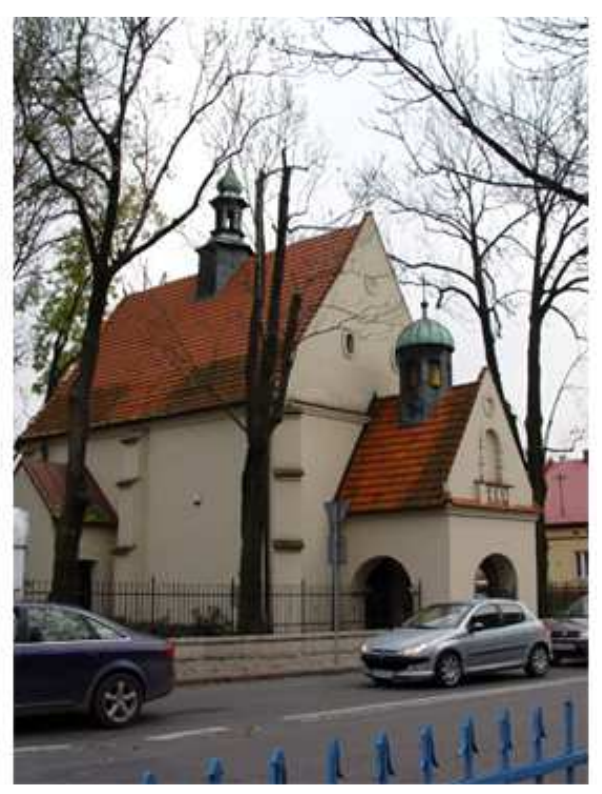

Ryc. 4. Kościół pw. NMP w Skawinie. Stan istniejący. Fot. M. Krupa, 2015 r.

Fig. 4. Church of Our Lady in Skawina. Present state. Photo: M. Krupa, 2015 


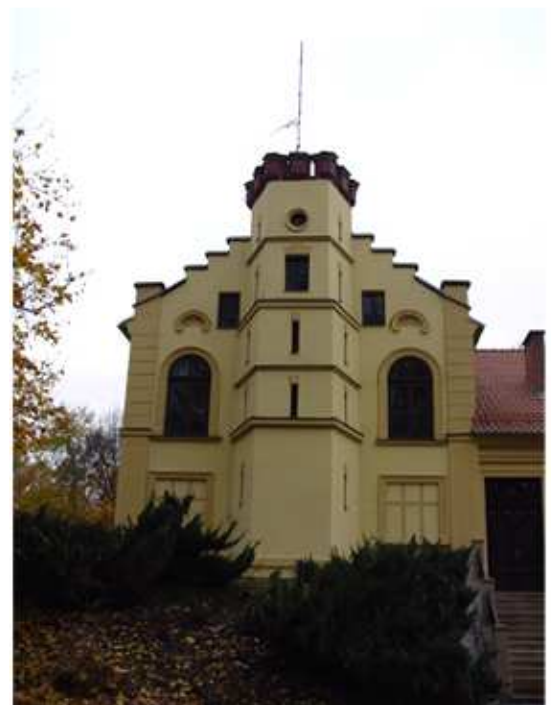

Ryc. 5. Fragment skawińskiego Sokoła. Stan istniejący. Fot. M. Krupa, 2015 r.

Fig. 5. Fragment of the Sokol in Skawina. Present state. Photo: M. Krupa, 2015

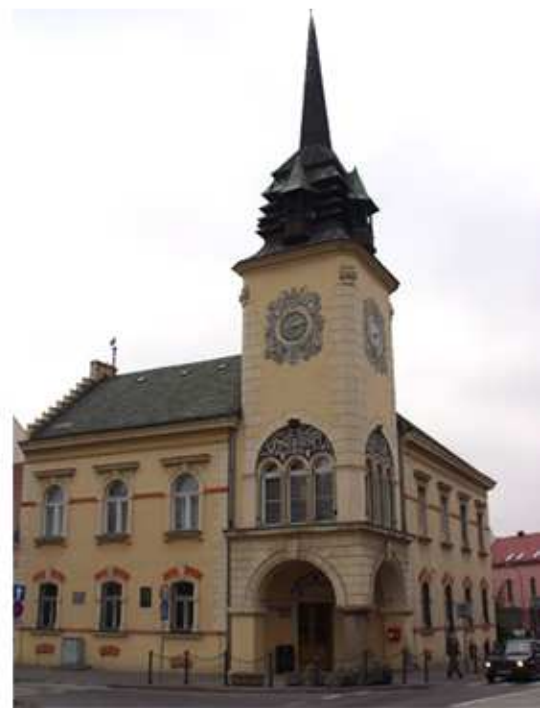

Ryc. 6. Widok na ratusz w Skawinie. Fot. M. Krupa, 2015 r.

Fig. 6. View of the town hall in Skawina. Photo: M. Krupa, 2015

\section{Współczesna zabudowa centrum Skawiny - wybrane przykłady}

Niewątpliwie jedną z najważniejszych inwestycji miasta w ciągu ostatnich lat jest modernizacja płyty skawińskiego rynku. Główny plac miejski Skawiny został rozmierzony w średniowieczu, w okresie lokacji miasta przez Kazimierza Wielkiego i ma on wymiary 90 x 112,5 m, gdzie wymiar dłuższy określa odległość między pierzeją północną i południową. Rynek został otoczony pojedynczym rzędem bloków zabudowy. Wyprowadzono z niego łącznie osiem ulic, po dwie z każdego narożnika. Dzisiaj układ ten różni się od pierwotnego. Z narożnika północno - zachodniego wychodzą dwie ulice (ul. Mickiewicza i ul. Batorego), z narożnika północno - wschodniego wychodzi jedna ulica (w kierunku wschodnim ul. Pokoju), z narożnika południowo-wschodniego jedna (w kierunku południowym ul. Konopnickiej), z narożnika południowo-zachodniego także jedna ulica (w kierunku południowym ul. Żwirki i Wigury), z rynku wychodzi także ul. Słowackiego ze środka pierzei wschodniej po jej wtórnym przebiciu w okresie nowożytnym. Na skawińskim rynku od czasu powstania miasta odbywał się handel. Miasto otrzymywało od kolejnych władców przywileje handlowe, co powodowało, że rynek skawiński tętnił życiem. Wokół rynku mieściły się domy mieszkalne, pierwotnie drewniane, które z czasem zastąpiła zabudowa murowana. Na rynku w przeszłości stał ratusz. Niestety o tym z okresu średniowiecza i kolejnych, które istniały przed ratuszem „Ekielskiego” niewiele wiadomo [5]. 
Analiza historii miasta oraz skawińskiego rynku pozwala na stwierdzenie, był on zawsze był odbiciem kondycji miasta. Lata upadku i zastoju w wieku XVIII i na pocz. XIX spowodowały, że rynek oraz otaczająca go zabudowa były zaniedbane. Dopiero w drugiej połowie XIX wieku i na początku XX, kiedy miasto zaczęło podnosić się z upadku dokonano uporządkowania placu. Wówczas w jego pierzei zachodniej wzniesiono nowy ratusz proj. W. Ekielskiego [6].

Okres drugiej połowy XX wieku to czas, kiedy rynek zaczął ponownie podupadać. Negatywnym zjawiskiem było tutaj (podobnie jak w wielu miastach) stopniowe obsadzanie przestrzeni rynkowej drzewami i krzewami. Na skawińskim rynku wydzielono także kwatery z klombami. Historyczna przestrzeń, zamykająca się w prostokątnym rzucie płyty rynku została przecięta lokalną drogą przelotową łączącą ul. Mickiewicza z ul. Słowackiego. Zabieg ten zakłócił właściwy odbiór tej przestrzeni jako rynku miejskiego o średniowiecznym rodowodzie.

Długo oczekiwana rewitalizacja tego najważniejszego skawińskiego placu została zakończona w 2013 roku. Dzięki funduszom unijnym przestrzeń została uporządkowana, a część drzewostanu, który zakłócał odbiór tego urbanistycznego wnętrza, usunięta. Realizowany projekt architektoniczny autorstwa Pracowni LandArch, choć trudno go uznać za szczególnie przemyślany w kontekście Skawiny, należy ocenić pozytywnie. $Z$ całą pewnością poprawił on jakość zaniedbanej i chaotycznej przestrzeni architektonicznej centrum miasta.

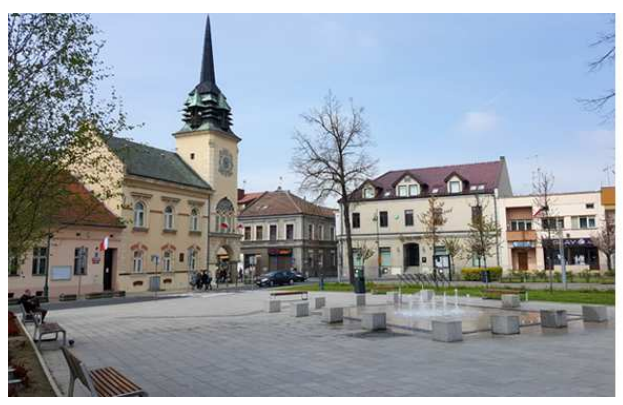

Ryc. 7. Widok na rynek w Skawinie od południowego-wschodu. Stan istniejący. Fot. M. Krupa, $03.2016 \mathrm{r}$.

Fig. 7. View of the market square in Skawina from the south-east. Present state. Photo: M. Krupa, 03.2016

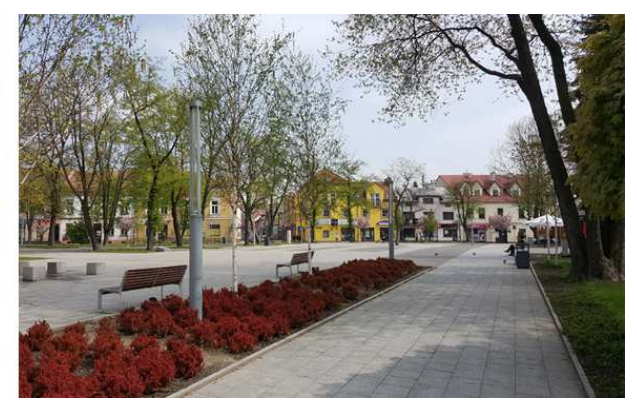

Ryc. 8. Widok na rynek w Skawinie od północnego-zachodu. Stan istniejący. Fot. M. Krupa 03.2016 r.

Fig. 8. View of the market square in Skawina from the north-west. Present state. Photo: M. Krupa 03.2016

Mniej udaną współczesną realizacją w centrum Skawiny jest przebudowa narożnej kamienicy w rynku oznaczonej numerem Rynek 13 i ul. Słowackiego 2. Budynek został wzniesiony na początku XX wieku na rzucie odwróconej litery „L”. Pierwotnie był parterowy, dwutraktowy i ośmioosiowy [7]. W roku 1996 został on bardzo rozbudowy o kolejne dwie kondygnacje. Wówczas zmieniono 
także podziały na elewacji. Tym samym, dom przy Rynku 13 nie przedstawia już wartości zabytkowych. Nie jest także atrakcyjny w swojej współczesnej „odsłonie”. Negatywne wrażenie tej nieudanej realizacji potęgują duże, chaotycznie zawieszone szyldy i reklamy oraz kolor elewacji.

Kolejną współczesną realizacją wartą odnotowania jest przebudowa kamienicy Rynek 24, która powstała w 1862 roku, na działce narożnej przy Rynku i ul. Batorego. Opisywany dom był pierwotnie obiektem parterowym, częściowo podpiwniczonym, wzniesionym na rzucie prostokąta. Do około połowy wieku XX budynek posiadał ciekawą dekorację $\mathrm{w}$ formie pilastrów i innych detali architektonicznych zaznaczonych w grubości tynku, nawiązujących do stylu klasycystycznego [8]. Dekoracja ta została zatarta podczas kolejnych remontów. Przełomowym czasem dla obiektu był 2011 rok, kiedy dokonano jego przebudowy. Dobudowano doń dwie kolejne kondygnacje (piętro oraz poddasze użytkowe). Zachowano pierwotne podziały elewacji (pięcioosiowość), w których początkowo oś środkową stanowiła przelotowa sień, a obecnie jest to wejście do budynku. Zasygnalizowano również (w formie uproszczonej) dawny detal. Podsumowując, należy stwierdzić, że zasadniczo realizacja ta należy do względnie udanych, aczkolwiek niedosyt stanowi lokalizacja lukarn w kondygnacji poddasza, która burzy porządek elewacji frontowej.

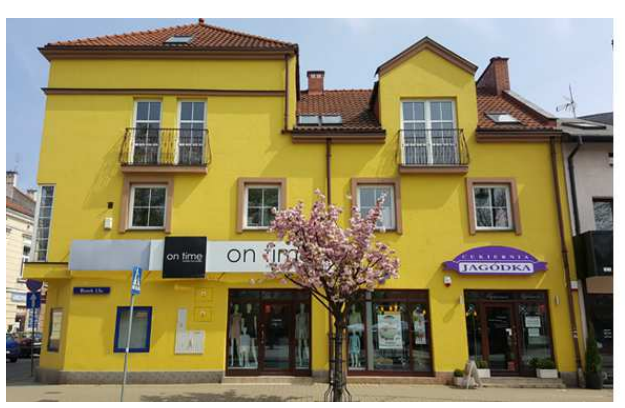

Ryc. 9. Widok na budynek Rynek 13 i ul. Słowackiego 2. Stan istniejący. Fot. M. Krupa $03.2016 \mathrm{r}$.

Fig. 9. View of the building at 13 Market Square and 2 Słowackiego Str. Present state. Photo: M. Krupa 03.2016

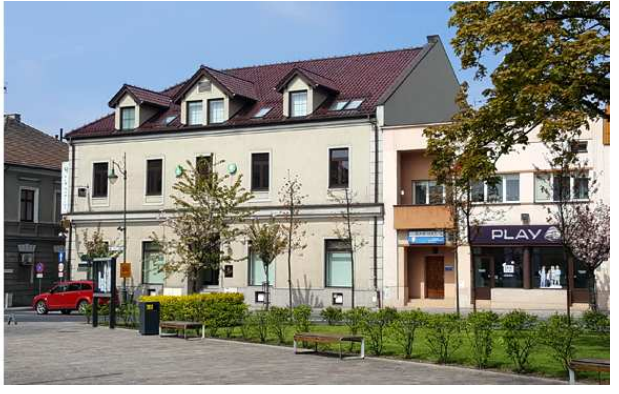

Ryc. 10. Widok na budynek Rynek 24. Stan istniejący. Fot. M. Krupa 03.2016 r.

Fig. 10. View of the building at 24 Market Square. Present state. Photo: M. Krupa 03.2016

Pisząc o nowych realizacjach w centrum Skawiny trzeba także skomentować przebudowę domu zlokalizowanego przy Rynku 21. Powstał on w drugiej poł. XIX wieku jako obiekt murowany z cegły, parterowy, dwutraktowy, trzyosiowy z sienią przelotową. Został wzniesiony na rzucie kwadratu. Elewacja frontowa posiadała wysoki cokół, była asymetryczna i czteroosiowa. Przed modernizacją obiekt posiadał dekorację $\mathrm{w}$ formie lizen pokrytych pseudorustyką wykonaną w tynku. Dom był przekryty dachem dwuspadowym z kalenicą równoległą 
do ulicy i pierzei rynku [9]. W roku 2011 przystąpiono do przebudowy tego zabytkowego obiektu, dobudowując doń piętro z poddaszem użytkowym, co spowodowało zmianę kompozycji jego elewacji frontowej. Należy jednak stwierdzić, że efekt końcowy jest zadawalający. Budynek został dobrze wpasowany $\mathrm{w}$ istniejącą pierzeję rynku, na co ma także wpływ jego stonowana kolorystyka.

Ostatnim prezentowanym $\mathrm{w}$ tym artykule przykładem nowej formy $\mathrm{w}$ zabytkowej tkance urbanistycznej Skawiny jest budynek usługowy wzniesiony w bezpośrednim sąsiedztwie XVII-wiecznego kościoła pw. NMP. Przykład ten odbiega zasadniczo od prezentowanych wcześniej ponieważ dotyczy nowego budynku. Powstał on w 2011 roku na działce przy ul. Korabnickiej 1, która prowadzi z rynku na obrzeża miasta. Posesja wcześniej zabudowana była parterowym domem o typowo małomiasteczkowej architekturze. Forma nowego obiektu jest ciekawa, prosta, stonowana i zdawać by się mogło, że została właściwie wpasowana w istniejący krajobraz kulturowy. Niestety w widoku zarówno od centrum miasta jak i od wschodu zdominowała ona całkowicie bryłę zabytkowego kościoła, który jest ważnym elementem krajobrazu historycznej Skawiny, Zatem dopuszczenie w MPZP takiej formy należy uznać za poważny błąd.

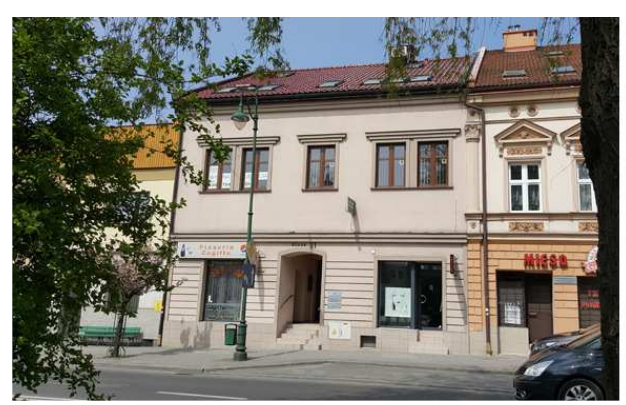

Ryc. 11. Widok na budynek Rynek 21. Stan istniejący. Fot. M. Krupa 03.2016 r.

Fig. 11. View of the building at 21 Market Square. Present state. Photo: M. Krupa 03.2016

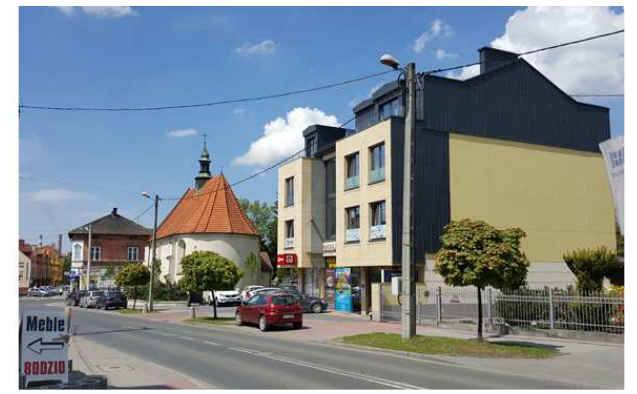

Ryc. 12. Widok na nowy budynek przy ul. Korabnickiej 1. Stan istniejący. Fot. M. Krupa $03.2016 \mathrm{r}$.

Fig. 12. View of the new building at 1 Korabnicka Str. Present state. Photo: M. Krupa 03.2016

\section{Podsumowanie}

Podsumowując niniejszy artykuł należy stwierdzić, że kierunek, w jakim zmierza współczesna architektura Skawiny, która powstaje w granicach historycznego układu urbanistycznego i jego otulinie, jest dość przypadkowy i nie skoordynowany przez władze miasta. Współczesne realizacje powstają jedynie według zasad wyznaczonych przez MPZP, który jak widać na części zaprezentowanych przykładów nie zawsze dość dobrze chroni krajobraz kulturowy miasta. Problem niezrozumienia m.in. przez niektórych architektów potrzeby ochro- 


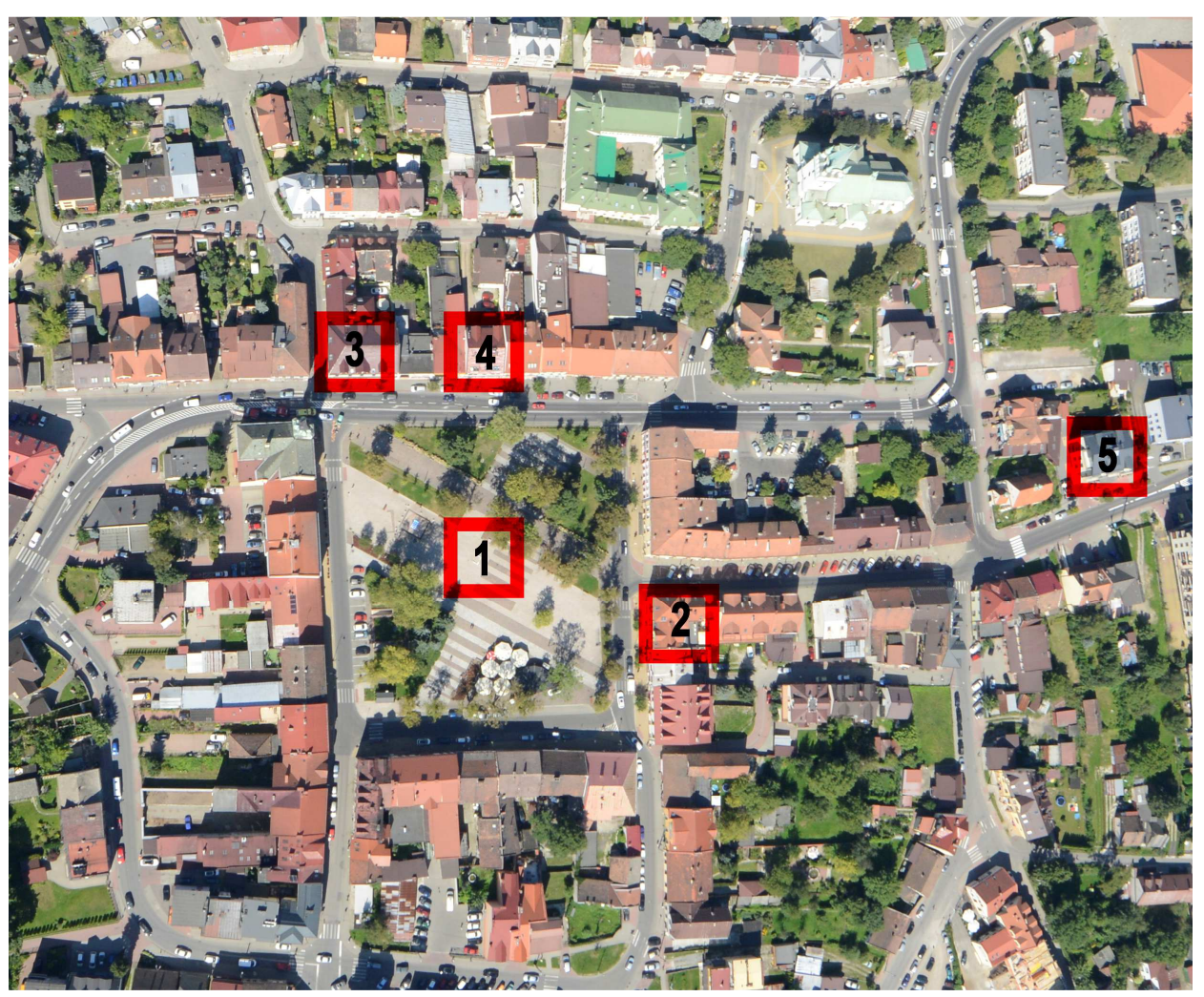

Ryc. 13. Ortofotomapa centrum Skawiny z oznaczeniem rynku oraz analizowanych realizacji architektonicznych: 1 - rynek, 2 - budynek Rynek 13 i ul. Słowackiego 2, 3 - budynek Rynek 24, 4 - budynek Rynek 21, 5 - budynek ul. Korabnicka 1. Na podstawie fot. W. Gorgolewskiego, opracował M. Krupa

Fig. 13. Orthophotomap of Skawina's centrum with marking of analysed architectural objects: 1 - market square, 2 - buildings at 13 Market Square and 2 Słowackiego St. 2, 3 - building at 24 Market Square, 4 - building at 21 Market Square, 5 - building at 1 Korabnicka St. Prep. M. Krupa based on photo by W. Gorgolewski

ny dziedzictwa miasta jest dobrze widoczny za przykładzie Skawiny. Projektowanie $\mathrm{w}$ środowisku zabytkowym jest dużym wyznaniem i odpowiedzialnością, gdyż można bezpowrotnie zniszczyć największe wartości ośrodka, wartości, które winne być zachowane dla kolejnych pokoleń, ale także, paradoksalnie mogą być szansą na jego rozwój np. poprzez turystykę kulturową. Postuluje się zatem, aby władze Skawiny zachowywały większą kontrolę nad prowadzonymi w centrum miasta inwestycjami budowlanymi, gdyż mogą one zniszczyć bezpowrotnie to co w mieście najcenniejsze - krajobraz kulturowy. 


\title{
Literatura
}

[1] Kuśnierz-Krupa D., Skawina w średniowieczu. Zagadnienia urbanistycznoarchitektoniczne, Wyd. PK, Kraków 2012, passim.

[2] Krupa M., Rozwój przestrzenny i architektura Skawiny w XIX i w 1 połowie XX wie$\mathrm{ku}$, praca doktorska obroniona na Wydziale Architektury Politechniki Krakowskiej, pod kierunkiem Prof. dr hab. inż. arch. J. Gyurkovicha, mpis, Kraków 2011, passim.

[3] Krupa M., Przemiany architektoniczne Skawiny na przełomie XIX i XX wieku. Część II - obiekty użyteczności publicznej / Architectonic transformations of Skawina at the turn of the 19th and 20th century. Part II - public utility buildings, "Wiadomości Konserwatorskie - Journal of Heritage Conservation" nr 42/2015, Wyd. ZG SKZ, Warszawa-Wrocław 2015, ss. 44-53.

[4] Krupa M., Przemiany architektoniczne Skawiny w 2 połowie XIX i na początku XX wieku. Część I - zakłady przemysłowe / Architectonic transformations of Skawina during the 2 nd part of the 19th and the beginning of the 20th century. Part I - industrial plants, "Wiadomości Konserwatorskie - Journal of Heritage Conservation" nr 35/2013, Wyd. ZG SKZ, Warszawa-Wrocław 2013, ss. 41-46.

[5] Skawina. Studium historyczno-urbanistyczne, T. I, II, III, opr. S. Rusińska, PP PKZ O. Kraków, PDN-H, mpis., Kraków 1978-79, passim.

[6] Chrzanowski T., Kornecki M., Sztuka Ziemi Krakowskiej, Wyd. Literackie, Kraków 1982, s. 521.

[7] Krupa M., Rozwój przestrzenny..., op.cit., s. 186.

[8] Skawina. Studium historyczno-urbanistyczne, T. I, op.cit., ss. 96-99.

[9] Ibidem, ss. 89-92.

\section{CONTEMPORARY ARCHITECTURE OF SKAWINA ON THE BACKGROUND OF HISTORIC HERITAGE OF THE TOWN}

\begin{abstract}
S u m m a r y
This article presents the problem of contemporary architectonic realisations in the centre of a historic town, such as Skawina near Krakow. The centre boasts rich cultural heritage, and its origins are connected with the politics of King Kazimierz Wielki who, in the borderlands in the 14th century, founded towns and fortified castles. In the 2 nd half of the 20th century, investments related to heavy industry were realised in the town, which had a definitely negative impact on the natural environment, as well as the cultural heritage of the town that fell into stagnation. In the eyes of many inhabitants, as well as visitors, Skawina became merely an industrial centre, while its historic roots and past fell into almost total oblivion. During the last 20 years, the town began to develop rapidly. Thanks to e.g. European funds, communications infrastructure was modernised and the market square was renovated, which encouraged town inhabitants and external investors to modernise the existing buildings, and fill some still empty sites with newly-built objects mostly intended for services and commercial use. Those investments have frequently been carried out in the historic centre of Skawina. The purpose of this article is analysing tendencies in the contemporary town architecture in the context of its history. The authors are trying to answer the question how new objects and alterations influence the cultural landscape of the town.
\end{abstract}

Keywords: Skawina, contemporary architecture, historic environment

DOI:10.7862/rb.2016.293

Przestano do redakcji: $15.05 .2016 \mathrm{r}$.

Przyjęto do druku: 20.12.2016 r. 
